\title{
DO FOOD QUALITY AND FOOD QUANTITY TALK THE SAME? LESSON FROM HOUSEHOLD FOOD SECURITY STUDY IN EMBO, SOUTH
}

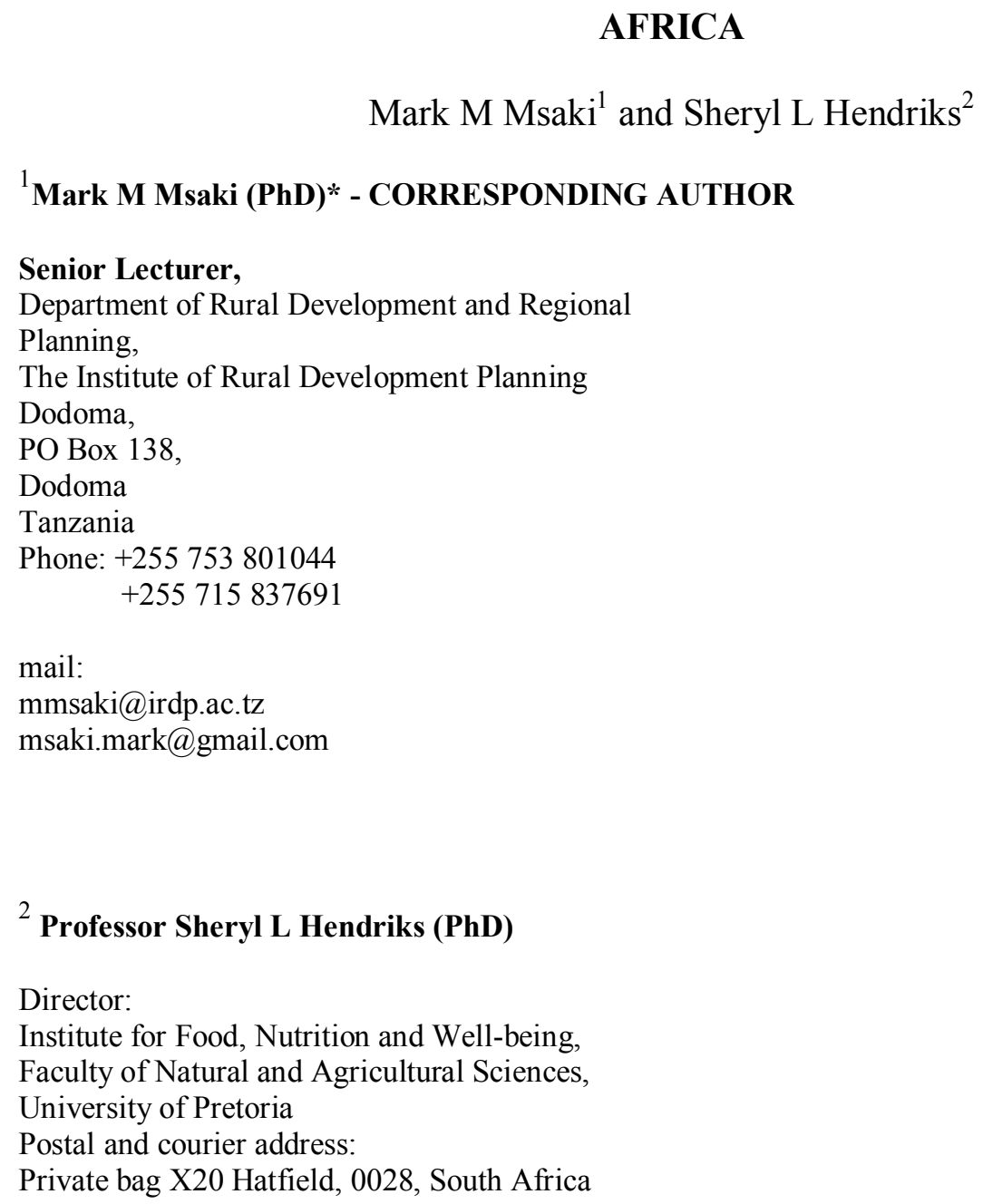

Key words: Household Food Intake Index; Nutrients Adequacy Ratio, Food Diversity, Food Quantity, Food Adequacy, Food Quality

\begin{abstract}
Objectives: Relating food diversity, quality, and intake is one of the key aspects in understanding household food security. This paper aimed at marying food intake and quality, both being measurement for food security.
\end{abstract}

Methods: A household food consumption survey $(n=200)$ exploring food diversity, quality of foods, and their relation to food intake in Embo, a poor farming community 
in rural KwaZulu-Natal was carried out in November 2004 (period of insufficiency) and repeated in March 2005 (period of plenty). Household food intake strata were developed using matrices obtained from the Household Food Intake Index and nutritional adequacy ratios. Food quality was measured using food count and later using 5 food groups, namely, starches, vegetables and fruits, animal sourced foods, fats, and legumes.

Results: Single food count showed dietary diversity to be significantly different across households with different food intake during the period of plenty $(P \leq 0.000)$. During the period of plenty, vegetable and fruits contributed significantly different proportions of energy $(P \leq 0.000)$, protein $(P \leq 0.006)$, iron $(P \leq 0.020)$, and vitamin $E(P \leq 0.006)$ to household food intake strata. Intake of vitamin $A$ was more elastic as its intake variation from legumes, fats, and animal sourced foods was $(P \leq 0.000)$, from starches $(P \leq 0.008)$ and from vegetable and fruits $(P \leq 0.064)$ during the second round. Starches are the most important food group to the community, whereas fats and animal sourced food groups are less important.

Conclusions: The current study has been able to include food quality in food security studies. Seasonality accounts for variation in food quality. The South African foodbased dietary guidelines are relevant to the Embo community.

\section{INTRODUCTION}

Dietary needs imply that the diet as a whole contains a mix of nutrients for human physical and mental growth, development and maintenance, and physical activity in compliance with human physiological needs at all stages throughout the life cycle and fitting to gender and occupation (Food and Agriculture Organisation, 1999). Dietary Diversity which is defined as the number of different foods or food groups consumed over a given reference period is key to quality diets (Swindale and Bilinsky, 2006). 
However, Swindale and Bilinsky (2006) further argued that the number of different food groups consumed, rather than the number of different foods consumed does reflect better the quality of food .

Seasonality of tree fruits, vegetables and kitchen garden fruits supply translates into seasonality in prices and ultimately consumption patterns (Sani, 2011). For farming families, crop diversity is related to dietary diversity and, ultimately, adequate nutritional intakes (Remans et. al, 2011). In both developing and industrialised countries, improved income increases accessibility to higher-quality foods (Farm and Food Policy Project, 2007; Swindale and Bilinsky, 2006; United Nations Children's Fund, 1998). In affordability of food has denied access to quality foods World Wide (Sydney Food Fairness Alliance, 2009). During 2011 social policies and measures, such as offering people small sums of money to use in affording the basics such as food has been important to avoid harmful survival strategies (UNICEF, 2011).

A large proportion of the South African population consumes diets low in nutrient density, specifically vitamin A, thiamin, riboflavin, niacin, folic acid, vitamin B6, iron, zinc and calcium (Grobbelaar et. al, 2004). The campaigns for increased dietary diversity and fortification of foods have been practiced in South Africa (Globbelaar et. al, 2004). "Enjoy a variety of foods" is the first of the ten South African FoodBased Dietary Guidelines (FBDGs), to encourage changes in diets to increase the variety of foods eaten. (Maunder et. al, 2001). Similarly, the National Food Consumption Survey (2000) recommended that fortification of maize (sifted, special and super), white and brown wheat flour and white sugar, should be mandatory in order to address this problem (Grobbelaar et. al, 2004). In South Africa, mandatory 
fortification of maize and wheat programme started in October 2003 (Grobbelaar et. al, 2004).

The current paper intended to explore the relationships between food intake and diversity, evaluating how healthy (quality) diets of Embo community a rural area of KwaZulu Natal are, and at the same time, understanding what types of food are principal for household food sufficiency. The study was also an opportunity to assess the relevance of the South African Food Based Dietary Guideline (FBDG) to Embo community. It is argued that understanding links between food intake, diversity and quality is important in determining household food security.

\section{Food Based Dietary Guidelines}

The World Health Organization (WHO), together with the Food and Agriculture Organization (FAO) of the United Nations recommends that member countries develop Food-Based Dietary Guidelines to address existent nutrition-related health problems (WHO, 2007). These FBDG should be based on prevailing eating patterns of the population, should include traditional and indigenous foods, should be sensitive to the culture of the population, should contain foods that are available, accessible and affordable, should consist of easily understandable messages, expressed in a positive way to motivate people to change dietary habits where necessary (Alasfoor et. al, 2013).

The presence of both undernutrition (in developing countries) and overnutrition (in developed and transition countries) has shifted the focus of nutritional adequacy to dietary quality (WHO, 1996). In the United States, the Dietary Guidelines encourage 
Americans to focus on eating a healthful diet - one that focuses on foods and beverages that help achieve and maintain a healthy weight, promote health, and prevent disease (Jones et. al, 2012). In South Africa, the Food Based Dietary Guidelines were first introduced in 1998 (Vorster et. al, 2001). Continuous monitoring of the impact of the guidelines has been mentioned as necessary for evaluating how successful implementation of the Food Based Dietary Guidelines has been (Alasfoor et. al, 2013).

\section{South African Food Based Dietary Guidelines}

The South African Food Based Dietary Guidelines consist of 10 short, clear and simple messages. As listed by Volster et. al, (2001), these guidelines are as follows:

1. Enjoy a variety of foods.

2. Be active.

3. Make starchy foods the basis of most meals.

4. Eat plenty of fruit and vegetables.

5. Eat dry beans, peas, lentils and soya often.

6. Meat, fish, chicken, milk and eggs can be eaten every day.

7. Eat fats sparingly.

8. Use salt sparingly.

9. Drink lots of clean, safe water.

10. If you drink alcohol, drink sensibly

Foods rich in carbohydrates in the form of starch, sugars and non-starch polysaccharides or dietary fibre, influence health and prevent chronic diseases by various effects and mechanisms (Jones et al, 2012). Vegetables and fruits are 
important sources of many vitamins, minerals, fibre and other substances necessary for body protective role, affordability, availability and taste preferences are primary constraints towards people intake of vegetables and fruits (National Health and Medical Research Council, 2005; Love and Sayed 2001). Legumes are recommended since they are rich and economical sources of good quality protein, carbohydrates, soluble and insoluble dietary fibre components and a variety of minerals and vitamins and at the same time are low in energy, fat and sodium (National Health and Medical Research Council, 2005). Recommending food from animals can be eaten everyday appreciated the role of animal sourced foods in providing high quality nutrients and essential micronutrients (Grillenberger et. al, 2006).

Eating fat and salt sparingly have been recommended for human health purposes. While overconsumption of fats is linked with Coronary Heart Disease, obesity and cancers such as breast, colon and prostate cancer (Yong et. al, 2009), overconsumption of salt is linked with high blood pressure "hypertension" (National Heart Foundation of Australia, 2007). Generally the guideline have been more or less similar worldwide (Alasfoor et. al, 2013; Jones et. al, 2007;

Principally, during food security and nutrition studies, there are no fixed criteria to determine nutrients to be examined, but rather nutrition elements important related to nutrition problems in the respective country (Ruel, 2003). Deficiencies of vitamin A, protein, iron and iodine have been frequently reported in rural of KwaZulu-Natal (Vella, 2003; Stuijveberg, 2001; Oelofse et. al, 1999). Importance of Vitamin E is based on the findings that lower plasma level of vitamin $\mathrm{E}$ as well as vitamin $\mathrm{A}$ and 
vitamin B12 are related to faster HIV/AIDS disease progression (Fawzi et. al, 2004) . South Africa has one of the highest HIV prevalence rates in the world. It has been estimated that 5,700,000 South Africans had HIV/AIDS, being an approximate of 12 $\%$ of South Africa's population of 48 million (UNAIDS, 2008). Respectively, KwaZulu-Natal is the most highly afflicted province in South Africa (Matthews et. al, 2008). In South Africa, dietary diversity and nutritional adequacy studies should focus on energy, protein, vitamin A, iron and iodine intakes - which have been reported to be deficient.

The present study investigates the relationship between household's dietary diversity and quality, and household food security. Household dietary diversity was analysed as both simple food count and later as five major food groups included in South African Food Based Dietary Guidelines (starch, vegetable and fruits, legumes, animal sourced foods and fats). Household food security took into account household intakes of energy, protein, iron, vitamin A and E. Relationships between household food security (food intake stratum) and food diversity (simple food count within five major food groups included in Food Based Dietary Guidelines) were determined. Proportions of household energy, protein, iron, vitamin A and E intake obtained from five major food groups were determined, and related to household food intake strata. The relationship between proportions of energy, protein and micronutrients to household intake strata was used to evaluate dietary quality. As household food intake information was obtained during two seasons, the relationship between household food security, food diversity and quality was determined across the seasons. 
With regards to the current paper, not only the relationship between household dietary diversity and food intake (sufficiency) was determined, but identification of food groups contributing more to household food intake was carried out. Learning the proportions of household energy, protein and nutrients obtained from food groups, has been an opportunity in understanding dietary quality for Embo community. The later has been important to assess whether the South African Dietary Based Guidelines are relevant to Embo rural community.

\section{Characteristics Of The Study Area}

Embo is a rural community in the Mbumbula District of KwaZulu-Natal. The Embo community was part of the former KwaZulu homeland. Rural and former homelands areas have been reported to be poorest in South Africa (Woorlard, 2002). Msaki and Hendriks (2013) reported that households (mean household size $=8$ ) had mean monthly income of R 2351 (USD 361.70), while income from non-farm activities averaged R 2310 (USD 355.38), per month. Among the households, $35.4 \%$ and 26.8 $\%$ of the households were found to have its members living under one and less than 2 dollars a day respectively displaying higher incidence of poverty as compared to the national figure (Msaki and Hendriks 2013; Department of Health, 2000). Located in a moist coastal hinterland region, only 15 percent of the total Mbumbula Bioresource Unit has high potential for annual cropping (Camp, 1995). The climate is favourable for a wide range of adapted crops and the area has a year-round growing season (Camp, 1995). Analysing cropping-harvesting overlap, October and February are months of hunger and harvest respectively (Msaki and Hendriks, 2013). The location of the study area is displayed in Figure 1. 


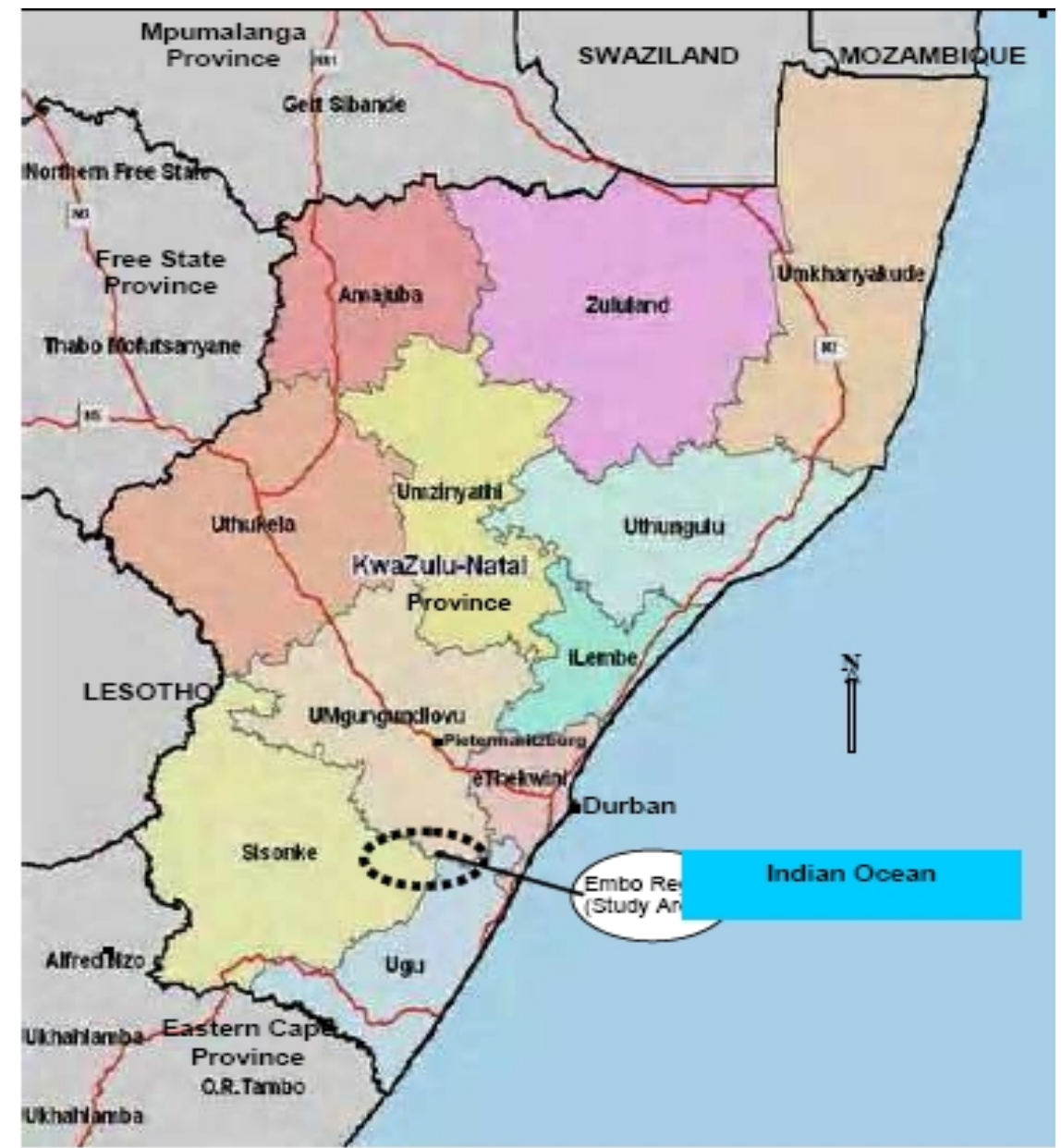

Figure 1: Location of study site in KwaZulu-Natal (Municipal Demarcation Board, 2006).

In the preliminary study by Msaki and Hendriks, (2013) the households obtained foods through purchases $(79 \%)$, own production $(17 \%)$, gifts $(3 \%)$ and as payment (1\%). The study found out that $75 \%, 58.4 \%, 78 \%, 76 \%$ and $47 \%$ of the households had insufficient intakes (below Recommended Dietary Allowance for Adult Female Equivalent) in terms of energy, protein, iron, vitamin A and $\mathrm{E}$ in the first round of November 2004, respectively. Similarly, $31 \%, 8.6 \%, 13 \%, 58 \%$ and $45 \%$ of the households were found to experience insufficient food intake in the second round of March 2005, respectively. Based on Adult Female Equivalents, the household mean per capita intakes for the surveyed households were found at 2007.50 $\mathrm{kcal} /$ day, $53.88 \mathrm{~g} /$ day, $11.28 \mathrm{mg} / \mathrm{day}, 612.72 \mu \mathrm{g} \mathrm{RE} /$ day, and $9.61 \mathrm{mg} /$ day for energy, protein, iron, vitamin $\mathrm{A}$, and vitamin $\mathrm{E}$, respectively for the first round. In the second 
round, the household per capita intakes were reasonably higher $3658.82 \mathrm{kcal} /$ day, $180.68 \mathrm{~g} /$ day, $54.33 \mathrm{mg} /$ day, $921.48 \mu \mathrm{g} \mathrm{RE} /$ day, and $10.60 \mathrm{mg} /$ day, respectively. The household mean food count for the first and second round was 20 and 26, respectively. High proportion of households with insufficient intakes, low per capita intakes and low diversity during the first round explains food insufficiency (hunger season) as compared to the second round (harvest season).

Using the Principal Component Analysis (Msaki and Hendriks, 2013), the Household Food Intake Index was developed, whereby energy, iron and protein were found to influence food intake variation among households. Dietary diversity caused least variation among household food intake. Only the adequate food intake strata (among three food intake strata - inadequate, moderate and adequate) had sufficient energy and nutrient intakes in the first round. In the second round, households from the inadequate food intake strata experienced insufficient intake of energy and vitamins A and E.

\section{MATERIALS AND METHODS}

Two consecutive household surveys $(n=200)$ were conducted in November 2004 and March 2005. The female household head was the person responding to the questionnaire, whereas in households without female household head, the responsible adult person was approached. As the number of foods consumed increases with time, periods more than two weeks have been suggested for accurate assessment of dietary diversity (Drewnowski et. al, 1997). For analysis purposes, food items were grouped by type of foods as recommended by the South African Food Based Dietary 
Guidelines as starchy foods (cereals and grains), fruit and vegetables, legumes (dry beans, peas, lentils and soya), animal foods (meat, fish, chicken, milk \& products and eggs) and fats (Swindale and Bilinsky, 2006; Vorster et. al, 2001).

In order to identify household food and nutrients available for the households, reported monthly expenditure on each food (from purchases, gifts, payments, and own production) was converted into masses and volumes using average prices obtained from informal local stores and Isipingo (the nearest commercial centre). Expenditure for all food consumed in the previous month was recorded as volumes and nutrients. Food volumes and masses were then converted into energy (kcal), protein (g), iron (mg), vitamin A ( $\mu \mathrm{g}$ Retinal equivalents) and vitamin E (mg) using food composition tables. It was assumed that all food procured was consumed by households. Nutrient losses were not taken into account as the study did not attempt to investigate nutritional status but compared potential nutrient intakes amongst the households. To control for household size, age and gender variations between households, energy and nutrient intakes and requirements were estimated as Adult Female Equivalents (15 and 50 years) based on Recommended Dietary Allowances (National Academy of Sciences, 1989). The data obtained were analysed using SPSS 16.0 software program.

Two methods were used to breakdown household adult female equivalent per capita intake values for energy, protein, iron, vitamin A and E, into aggregate values (indices). The methods used to prepare household food intake were the Principal Component Analysis (recently developed) following Msaki and Hendriks, (2013) and Nutrient Adequacy Ratio (traditionally used) following Kreb-Smith et. al, (1987) and 
Rose and Tschirley, (2000). As employed by Msaki and Hendriks, (2013), the Principal Component Analysis was used to prepare a Household Food Intake Index which was used to estimate household food intake adequacy. The method was useful in estimating the strength of the variables (energy protein and micro nutrients) in influencing household's energy and nutrients intake variation. Involving both the new and present used methods in food security studies is advised to cross check if after all the new methods are empirical.

The Principal Component Analysis (PCA) involved breaking down household energy, protein and micronutrients per capita intakes (with regards to female adult equivalents) into categorical or interval variables. The variables were then processed in order to obtain weights and principal components. The result obtained from the first principal component (explaining the most variability) was used to develop the Household Food Intake Index based on the formula:

$A j=f 1 \times(a j i-a 1) /(S 1)+\ldots \ldots f N \times(f a j N-a N) /(s N)$ (Filmer and Pritchett, 1998)

$A j$ represent Household Food Intake Index, $f 1$, scoring factors or coefficients for each set of nutrient items (energy, protein, iron, vitamin A and E). $a$, household score in the particular nutrition item. $a j$, is the value for the nutrition item, where $a l$ and $s l$ are the mean and standard deviation of the nutrient item, respectively.

This analysis has been widely used to estimate wealth of households using socioeconomic indicators such as assets owned, household amenities and incomes (Booysen 2003). In household food security studies, this formula has been used in 
identification of household's socio-economic status, and regressed to food availability (Lorenzana and Sanjur 1999; Rose and Charlton 2002). In the present analysis, Principal Component Analysis is used to estimate household food adequacy and strength of the variables (nutrients) in causing households intake variation amongst the community.

Based on household intake, indices were used to categorise households into three equally sized groups using 33.3 and 66.6 percentiles. The three groups represented households with inadequate, moderate and adequate food intakes. Household food intake categories were later regressed to household dietary diversity with reference to South African Food Based Dietary Guidelines.

Analysis of Variance (ANOVA) was used to compare mean household food counts (Food Variety Score) from each of the five food groups (starchy, vegetable and fruits, legumes, fats and animal foods). The Duncan Multiple Range test conducted at $1 \%$ level of significance was used to explain food groups' homogeneity of variation across food intake categories. Duncan Multiple Range test is a more powerful (in the statistical sense) alternative to almost all other post hoc methods and provides significance levels for the difference between any pair of means, regardless of whether a significant $\mathrm{F}$ resulted from an initial analysis of variance (Frey, 2010).

Dietary quality was determined by calculating proportions (percent of energy, protein and micro nutrients) for the households which have been obtained from the five food groups (starchy, vegetable and fruits, legumes, fats and animal foods). At the same time, the differences between proportions of food intake from five food groups and 
household food intake strata, suggested the food groups necessary for food sufficiency. Since the analysis was done using data collected during two seasons, the dietary quality across the seasons was determined.

\section{RESULTS}

The Household Food Intake Index (Msaki and Hendriks 2013), revealed that during the two rounds of survey, dietary diversity (based on Food Variety Score) was almost equal amongst households with inadequate, moderate and adequate food intake. For common understanding, household food intake was determined using both the Household Food Intake Index and the Nutrient Adequacy Ratio. Employing percentiles at 33.3 and 66.6 , the household indices prepared by both methodologies were categorised into 3 equal sized groups, being adequate, moderate and inadequate food intake category of households. The 33.3 and 66.6 cut-off values for the first round were -0.4695 and 0.0044 for Household Food Intake Index while they were 2.64 and 4.06 for Nutrient Adequacy Ratio index. In the same respect, the cut-off values were -0.8004 and -0.61 for the Household Food Intake Index while they were 4.19 and 4.91 for Nutrient Adequacy Ratio index in the second round.

The common feature for both Household Food Intake Index and Nutrient Adequacy Ratio tools is that the bigger score for household indicates more food intake for the household. The difference between Household Food Intake Index and Nutrient Adequacy Ratio is that while the households' scores developed through Nutrition Adequacy Ratio methodology easily interpret household food sufficiency (i.e. households with sufficient energy, protein, iron, vitamin A and E have a score of 5), the household matrices obtained through the Household Food Intake Index are only 
useful in the preparation of household food intake quintiles (inadequate, moderate and adequate).

As displayed in Table 1, cut offs made at the index prepared by the Nutrient Adequacy Ratio methods explained that households whose intake was below ( 2.64 / 5

* 100) percent and $(4.19 / 5 * 100)$ percent were regarded as inadequate intake households in both the first and second round, respectively. Household food intake was much more improved in the second round (March 2005) as compared to the first round (November 2004).

Table 1. Cut-offs for households' food intake strata, Embo, November 2004 and March 2005.

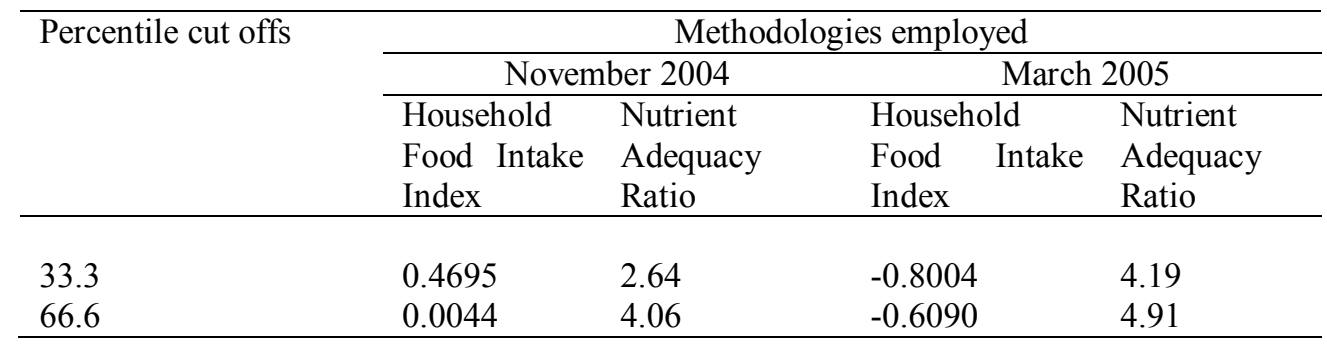

Since the Household Food Intake Index was the new instrument, the commonality of tools across seasons was assessed with reference to categorisation of households' intake strata (see Table 2). As presented in Table 2, the classification in the first round is very similar to the second round. Converting displayed figures into percentages, both tools showed that, $95.5 \%, 86 \%$ and $90.9 \%$ of households had inadequate, moderate and adequate food intakes respectively in the first round. 
Table 2. Coherence of household food intake classification tools, Embo, November 2004 and March 2005.

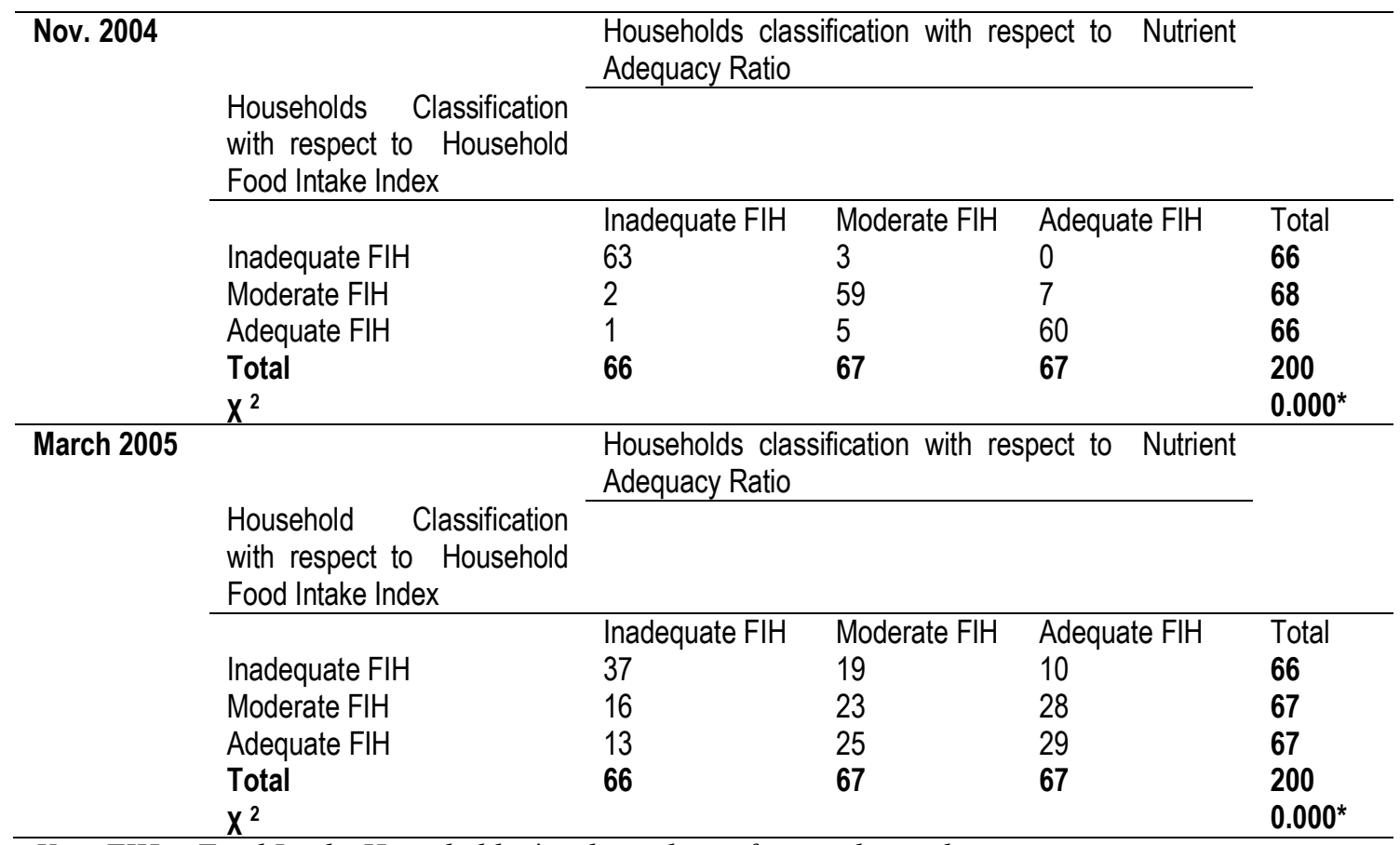

Key: FIH = Food Intake Households, * indicated significant relationship

During the second round, both tools revealed that 37 (56.1) \% (23) $34 \%$ and (29) 43 $\%$ of the households which were identified as having inadequate, moderate and adequate food intakes. The relationships between the Household Food Intake Index and the Nutrient Adequacy Ratio were statistically significant in both rounds $(\mathrm{P} \leq$ $0.000)$.

Summing of number of households taking particular food types during a previous month was done to determine the popularity of food items. The tallying provided the number and proportion of households which consumed the particular food item during the previous month. The mean count of food items in the particular food group (i.e starch, fruits/vegetable, animal food, fats and legume) was used to present the specific food group diversity. As shown in Table 3, starches were the most diverse food group 
in both rounds, being 6.80 and 8.67 for the first and second round respectively. The legume group of foods had the lowest diversity for both rounds. In all food groups, diversity had increased in the second round as compared to the first one.

Table3: Diversity in food groups and frequencies among food taken, Embo, November 2004 and March 2005.

\begin{tabular}{|c|c|c|}
\hline Time & Food type (diversity) & Proportion ( $\%$ ) of household consuming each food item $(n=200)$ \\
\hline \multirow[t]{5}{*}{$\begin{array}{l}\text { November } \\
2004\end{array}$} & Starch $(6.80)$ & $\begin{array}{l}\text { Rice (97.5), Potatoes (93.5), Sugar (97), bread (89), maize meal (86), } \\
\text { stamped maize (69), wheat flour (63), sweet potato ( } 29.5) \text {, madumbe } \\
(24.5) \text {, breakfast cereal (11), green mealie (5), }\end{array}$ \\
\hline & Vegetable/fruits (4.95) & $\begin{array}{l}\text { Tomato (82), wild vegetables (69.5), banana (61), citrus (59.5), apple } \\
\text { (57), carrot/beet root (45), green vegetable (42.5), jam (38.5), pumpkin } \\
\text { (25), tinned fruits (4.1), }\end{array}$ \\
\hline & $\begin{array}{l}\text { Animal foods }+ \text { Fish } \\
(5.00)\end{array}$ & $\begin{array}{l}\text { Chicken (92), meat (74.5), milk powders }(73) \text {, eggs }(69) \text {, processed } \\
\text { meats (40), offal (38), packed fish (25.5), sour milk (38.5), milk (33.5), } \\
\text { cheese (12.5), fresh fish (4.5), }\end{array}$ \\
\hline & Fats (1.63) & Cooking Oil (84.5), margarine (68.5), peanut butter (31), \\
\hline & Legumes (0.91) & Dry beans $(85)$, peanuts $(10.5)$ \\
\hline \multirow[t]{6}{*}{$\begin{array}{l}\text { March } \\
2005\end{array}$} & & \\
\hline & Starch (8.67) & 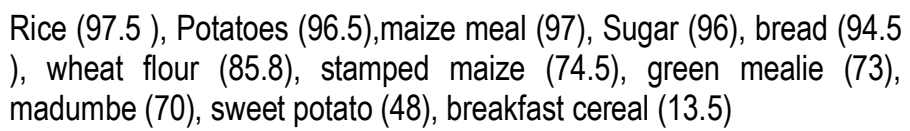 \\
\hline & Vegetable/fruits (5.78) & $\begin{array}{l}\text { Tomato (89), wild vegetables (83), apple }(77) \text {, banana }(68) \text {, pumpkin } \\
(60) \text {, jam (54), citrus }(51) \text {, carrot/beet root }(45) \text {, green vegetable } \\
\text { (42.5), tinned fruits (9), }\end{array}$ \\
\hline & $\begin{array}{l}\text { Animal foods+ Fish } \\
(5.33)\end{array}$ & $\begin{array}{l}\text { Chicken (92.5), meat (85), milk powders ( } 77.5) \text {, eggs (66), sour milk } \\
(52) \text {, processed meats ( } 45) \text {, milk (41.5), packed fish ( } 31.5) \text {, offal } \\
(27.5) \text {, cheese (11.5), fresh fish (3), }\end{array}$ \\
\hline & Fats $(2.17)$ & Cooking Oil (96.5), margarine (86.5), peanut butter (34), \\
\hline & Legumes (1.05) & Dry/green beans (84.5), peanuts (21) \\
\hline
\end{tabular}

Diversity of animal and fat foods maintained the third and fourth positions in both rounds. The major reason behind this is that these products are not influenced by local seasonality. On average there were 5 and 2 types of animal foods and fats consumed by households in each round. The proportion of households that consumed each food item was reported in percentages to explain the popularity of each food type.

While, rice, potatoes, sugar, bread, and maize meal are starchy foods consumed most frequently in both rounds, tomatoes and wild vegetable were food mostly frequent in 
the vegetable/fruits category. Chicken, meat, milk powder and eggs were popular foods from animal sources in both rounds. Cooking oil was the most frequently consumed food in the fats group of food. Dry bean was popular legume taken. Breakfast cereals, tinned fruits, fresh fish, peanut butter and peanuts were consumed by fewer households.

Using the Analysis of Variance test, the food intake categories developed through both the Household Food Intake Index and Nutrition Adequacy Ratios were regressed to respective dietary diversity for each round (Table 4).

Table 4. Relationship between food intake and dietary diversity, Embo, November 2004 and March 2005

\begin{tabular}{|c|c|c|c|c|c|c|}
\hline \multirow{2}{*}{$\begin{array}{l}\text { Period } \\
\text { Nov. } \\
2004 \\
\end{array}$} & \multirow{2}{*}{$\begin{array}{l}\text { Classification criteria/ } \\
\text { intake categories }\end{array}$} & \multicolumn{5}{|c|}{ Food groups } \\
\hline & & Starch & Legume & Veg/fruits & Fats & Animal foods \\
\hline & $\begin{array}{l}\text { Household Food Intake Index } \\
\text { Inadequate FIH }\end{array}$ & $7.05^{a}$ & $0.97^{a}$ & $4.80^{a}$ & $1.65^{a}$ & $5.24^{a}$ \\
\hline & Moderate FIH & $6.90^{a}$ & $0.96^{a}$ & $4.94^{\mathrm{a}}$ & 1.69 a & $5.10^{a}$ \\
\hline & Adequate $\mathrm{FIH}$ & $6.47^{\mathrm{a}}$ & $0.93^{a}$ & $5.13^{a}$ & $1.59 \mathrm{a}$ & $4.67^{\mathrm{a}}$ \\
\hline & $\begin{array}{l}\text { ANOVA } \\
\text { Nutrient Adequacy Ratios }\end{array}$ & 0.191 & 0.940 & 0.743 & 0.612 & 0.343 \\
\hline & Inadequate $\mathrm{FIH}$ & $6.94^{a}$ & $0.97^{a}$ & $4.66^{a}$ & $1.67^{a}$ & $5.14^{\mathrm{a}}$ \\
\hline & Moderate FIH & $6.85^{a}$ & $0.97 \mathrm{a}$ & $4.95^{a}$ & 1.64 a & $4.93^{a}$ \\
\hline & Adequate $\mathrm{FIH}$ & $6.63 \mathrm{a}$ & $0.93 a$ & $5.24 \mathrm{a}$ & $1.60 \mathrm{a}$ & $4.96 \mathrm{a}$ \\
\hline & ANOVA & 0.618 & 0.836 & 0.382 & 0.837 & 0.857 \\
\hline \multirow{9}{*}{$\begin{array}{l}\text { March } \\
2005\end{array}$} & \multicolumn{6}{|l|}{ Household Food Intake Index } \\
\hline & Inadequate FIH & $8.95^{b}$ & $1.18^{a}$ & $6.27^{a}$ & $2.05^{a}$ & $5.20^{a}$ \\
\hline & Moderate FIH & $8.82^{b}$ & $1.00^{a}$ & $5.63^{a}$ & $2.25^{a}$ & 5.49 a \\
\hline & Adequate $\mathrm{FIH}$ & $8.23^{a}$ & $0.99 a$ & $5.44^{a}$ & $2.21 \mathrm{a}$ & $5.30^{a}$ \\
\hline & $\begin{array}{l}\text { ANOVA } \\
\text { Nutrient Adequacy Ratios }\end{array}$ & 0.280 & 0.112 & 0.183 & 0.179 & 0.740 \\
\hline & Inadequate FIH & $7.97^{\mathrm{a}}$ & $1.02^{\mathrm{a}}$ & $4.67^{a}$ & 1.89 a & $4.64^{\mathrm{a}}$ \\
\hline & Moderate FIH & $8.73^{b}$ & $0.99 a$ & $5.88^{b}$ & $2.16^{b}$ & $5.22^{b}$ \\
\hline & Adequate FlH & $9.30^{c}$ & $1.16^{a}$ & $6.78^{c}$ & $2.45^{c}$ & $6.12^{c}$ \\
\hline & ANOVA & $0.000^{*}$ & 0.185 & $0.000^{*}$ & $0.000^{*}$ & $0.000^{*}$ \\
\hline
\end{tabular}

Key: FIH = Food Intake Households

The Duncan Multiple Range (Homogeneity of variances) test was performed at $1 \%$ level of significance. $a$ and $c$ indicates the lowest and highest mean diversity. ${ }^{*}$ indicates significant difference. 
As indicated in Table 4, there was no variation in diversity observed amongst the food intake categories during the first round. Both the homogeneity of variances (Duncan Multiple Range test) and the Analysis Of Variances (ANOVA) test showed that food diversity (among food groups) was not significantly different across food intake strata. Indifference between food group diversity across household food intake strata derived by both Household Food Intake Index and Nutrition Adequacy Ratios explained similarity of the two food intake indices.

In the second round, the analyses of homogeneity of variation for food diversity across the food intake stratum developed by Household Food Intake Index showed that households with inadequate and moderate food intakes had relatively high diversity in starch group of foods. However, the analysis of vegetable and fruit diversity variation (ANOVA) among the household food intake strata developed by Household Food Intake Index revealed that the variation was not significant.

Differently from the analysis done using food intake strata developed by the Household Food Intake Index, the Analysis Of Variances derived from the Nutrient Adequacy Ratio Index showed that diversities of starch, vegetables and fruits, fats and animal foods were significantly different among the household food intake categories. Using strata developed using the Nutrient Adequacy Ratio Index, positive relationships were found to exist between food intake strata in one hand and starch, vegetables and fruits, fats and animal foods diversity in the other hand. In all food groups, the households with adequate food intake were found to have highest diversity, followed by moderate and inadequate food intake households respectively. 
The analysis relating food intake to diversity showed several observations. First, is the fact that the diversity did not vary much during the hunger /off season period (November 2004) as it did during the harvest season (March, 2005). This suggested that households that had sufficient food intake during the first round capitalised on either higher food quantities or foods with rich nourishment than food diversity. Current findings suggest that food diversity is directly related to food intake. This argument is significantly supported by the trend expected and observed in the second round where more food intake was positively related with food diversity.

Leaving alone the case of legumes group of food (which was limited in diversity), increased diversity of all the other groups of food were found to be potential in increasing household food intake. In order to assess household dietary quality and how it is related to household food intake, the proportion of energy, protein, iron, vitamin $\mathrm{A}$ and $\mathrm{E}$ obtained from starch, legume, vegetables and fruits, fats and animal foods was determined (Table 5). As observed before, the Household Food Intake Index and Nutrient Adequacy Ratios have been providing similar results in household food intake assessments.

The Household Food Intake Index was found to be as efficient as the Nutrient Adequacy Ratios in analysis of household food intake and its relationship to diversity during the period of less (November, 2004), as compared to periods of plenty (March, 2005). During March 2005, the categories for food intake households developed through Nutrient Adequacy Ratios was found to be more sensitive to food diversity than categories for food intake households developed using Household Food Intake Index. Basing on the current findings, the Nutrient Adequacy Ratios was 
suggested to be employed in assessing the dietary quality of households as it showed to be more sensitive to household food diversity.

Table 5. Proportion (per cent) of household energy/nutrient delivered from food types November 2004/ March 2005

\begin{tabular}{|c|c|c|c|c|c|c|c|c|c|c|}
\hline \multirow[t]{2}{*}{$\begin{array}{l}\text { Element / } \\
\text { households }\end{array}$} & \multicolumn{5}{|c|}{ November 2004} & \multicolumn{5}{|c|}{ March 2005} \\
\hline & Starchy & Legume & Veg/fruit & Fats & Animal & Starchy & Legume & Veg/fruit & Fats & Animal \\
\hline \multicolumn{11}{|l|}{ Energy } \\
\hline Inadequate $\mathrm{FIH}$ & $77.99 \mathrm{a}$ & $5.88^{a}$ & $1.44^{a}$ & $12.60^{a}$ & $1.11^{a}$ & $49.96^{a}$ & 39.34 a & $1.02^{a}$ & $6.54^{a}$ & $3.15^{\mathrm{a}}$ \\
\hline Moderate FIH & $78.83^{a}$ & 5.91 a & $1.52^{\mathrm{a}}$ & 11.37 a & $2.37 a$ & $43.86^{a}$ & $46.63^{a}$ & $1.02^{b}$ & 5.47 a & $3.02^{a}$ \\
\hline \multirow[t]{2}{*}{ Adequate $\mathrm{FIH}$} & $\begin{array}{r}80.16^{a} \\
\text { ANOVA }\end{array}$ & $6.11^{a}$ & $1.63^{b}$ & $9.46^{\mathrm{a}}$ & $2.64^{a}$ & $46.39^{a}$ & $41.77^{a}$ & $1.85^{b}$ & $6.24^{a}$ & $3.75^{a}$ \\
\hline & 0.573 & $0.000^{*}$ & 0.938 & $0.000^{*}$ & 0.744 & 0.203 & 0.201 & $0.000^{*}$ & 0.176 & 0.129 \\
\hline \multicolumn{11}{|l|}{ Protein } \\
\hline Inadequate $\mathrm{FIH}$ & $60.03^{a}$ & $15.66^{a}$ & $2.34^{a}$ & $0.34^{a}$ & $21.73^{a}$ & $33.56^{b}$ & 56.49 a & $1.09 a$ & $0.17^{a}$ & $8.68^{a}$ \\
\hline Moderate FIH & $62.18^{a}$ & $15.89 \mathrm{a}$ & $2.70^{a}$ & $0.55^{a}$ & $18.68 \mathrm{ab}$ & $24.01^{a}$ & $67.67^{b}$ & $0.92^{a}$ & $0.16^{a}$ & 7.24 a \\
\hline \multirow[t]{2}{*}{ Adequate $\mathrm{FIH}$} & $\begin{array}{r}64.25^{a} \\
\text { ANOVA }\end{array}$ & $15.71^{a}$ & $2.47^{a}$ & $0.45^{\mathrm{a}}$ & $17.12^{a}$ & $28.54 \mathrm{ab}$ & $60.51 \mathrm{ab}$ & $1.79^{b}$ & $0.14^{a}$ & $9.03^{a}$ \\
\hline & 0.219 & 0.989 & 0.401 & 0.353 & 0.059 & $0.044^{*}$ & 0.084 & $0.006^{*}$ & 0.802 & 0.374 \\
\hline \multicolumn{11}{|l|}{ Iron } \\
\hline Inadequate $\mathrm{FIH}$ & $55.62^{a}$ & $27.14^{a}$ & $15.84 \mathrm{a}$ & $0.16^{a}$ & $1.24 \mathrm{a}$ & $29.08^{b}$ & $62.73^{a}$ & $5.99 a$ & $0.05^{a}$ & $2.15^{a}$ \\
\hline Moderate FIH & $53.83^{a}$ & $22.77^{a}$ & $20.89^{a}$ & $0.21^{a}$ & $2.30^{a}$ & $19.81^{a}$ & $73.86^{a}$ & $4.74^{a}$ & $0.05^{a}$ & $1.53^{a}$ \\
\hline \multirow[t]{2}{*}{ Adequate $\mathrm{FIH}$} & $\begin{array}{r}54.96 \text { a } \\
\text { ANOVA }\end{array}$ & $23.40^{a}$ & $18.91 \mathrm{a}$ & $0.16^{a}$ & $2.57 a$ & $23.44 \mathrm{ab}$ & 64.96 a & $9.71 \mathrm{~b}$ & 0.04 a & $1.85^{a}$ \\
\hline & 0.833 & 0.196 & 0.115 & 0.585 & 0.201 & 0.072 & 0.094 & $0.020^{*}$ & 0.687 & 0.292 \\
\hline \multicolumn{11}{|l|}{ Vitamin A } \\
\hline Inadequate $\mathrm{FIH}$ & $26.19 \mathrm{a}$ & $1.71^{b}$ & $48.89 a$ & $22.04^{b}$ & $1.17^{a}$ & $33.62^{a}$ & $15.16^{b}$ & $33.26^{a}$ & $8.21^{b}$ & $9.75^{b}$ \\
\hline Moderate FIH & $37.82^{b}$ & $1.64^{b}$ & $42.85^{a}$ & $13.25^{a}$ & $4.44^{a}$ & $39.30^{\mathrm{a}}$ & $5.82^{a}$ & $45.43^{b}$ & $5.18^{a}$ & $4.27^{b}$ \\
\hline \multirow[t]{2}{*}{ Adequate FIH } & $\begin{array}{r}46.24 b \\
\text { ANOVA }\end{array}$ & $0.74 a$ & $41.91 \mathrm{a}$ & $7.97 a$ & $3.13^{a}$ & $50.59 b$ & $3.21 \mathrm{a}$ & $40.69 \mathrm{ab}$ & $2.87^{a}$ & $2.64^{a}$ \\
\hline & $0.003^{*}$ & $0.035^{*}$ & 0.533 & $0.002^{*}$ & 0.169 & $0.008^{*}$ & $0.000^{*}$ & 0.064 & $0.000^{*}$ & $0.000^{*}$ \\
\hline \multicolumn{11}{|l|}{ Vitamin E } \\
\hline Inadequate $\mathrm{FIH}$ & $14.94^{a}$ & $0.00^{a}$ & $5.46^{b}$ & $68.01^{a}$ & $11.59^{b}$ & $16.68^{a}$ & $0.76^{a}$ & $2.38^{a}$ & $75.22^{b}$ & $4.96^{a}$ \\
\hline Moderate FIH & $17.19 \mathrm{ab}$ & $0.22 b$ & $3.07 a$ & 74.29 a & 5.24 a & $20.62 a b$ & 0.14 a & $3.24 \mathrm{ab}$ & $70.39 a b$ & 5.61 a \\
\hline \multirow[t]{2}{*}{ Adequate $\mathrm{FIH}$} & $\begin{array}{l}20.80^{a} \\
\text { ANOVA }\end{array}$ & $0.32^{b}$ & $2.87^{a}$ & $70.81^{a}$ & $5.20^{a}$ & $23.84^{b}$ & $0.70^{a}$ & $3.93^{b}$ & $66.48^{a}$ & $5.05^{a}$ \\
\hline & 0.104 & $0.008^{*}$ & $0.002^{*}$ & 0.336 & $0.000^{*}$ & $0.044^{*}$ & 0.084 & $0.006^{*}$ & 0.802 & 0.374 \\
\hline
\end{tabular}

Key: FIH = Food Intake Households, The Duncan Multiple Range (Homogeneity of variances) test was performed at $1 \%$ level of significance. a and $c$ indicates the lowest and highest percentage proportion of household energy / nutrients delivered from food types. * indicates significant difference.

Identification of proportions of energy, protein and micronutrients obtained from food groups was important not only in cross checking the relationship between food intake and diversity but also in identifying potential foods types (foods that matters) for the households.

As presented in Table 5, vegetables and fruit have been the most important group of foods causing variation of intake amongst households. The influence of the food 
group was rated by counting the frequencies and significances obtained by Analysis Of Variances tests. There was a significant and positive relationship between household food adequacy and nutritional benefits from vegetable and fruits. During the first round, vegetable and fruits contributed significantly higher proportions of vitamin $\mathrm{E}$ to households with adequate food intake. During the second round, vegetable and fruits contributed significantly higher proportions of all nutrients assessed with an exception to vitamin A to the households with adequate food intake. Counting the recurrence of significant values, vegetables and fruits scored the highest (5), favouring the adequate food intake households. The inadequate food intake households were found to have the least proportions of energy, protein and micronutrients obtained from vegetable and fruits.

Starches and legume foods were the second most variation influencing group of foods. There has been a significant positive relationship between household food adequacy and nutritional benefits from starch and legume foods. With an exception to vitamin A, starchy foods contributed almost equally to all households during the first round. During the second round, starchy foods contributed significantly higher proportions of, protein, vitamin A and vitamin E to the households with adequate food intake. Legumes significantly contributed higher proportion of Vitamin E (to inadequate food intake households) and Vitamin A (to adequate food intake households) for round 1 and 2 respectively. Legumes also contributed significantly higher proportions of energy to households with adequate intake during first round Counting on recurrence of significances, both starchy and legumes groups of food scored 4. 
Fat foods have been the third most important influencing group of foods. However, there has been a negative relationship between household food adequacy and proportion of nutritional benefits from fats. During the first round, fats contributed significantly higher proportion of Vitamin A to households with low food intake. In second round, fats contributed significantly higher proportions of Vitamin A and E to households with inadequate food intakes. Counting the recurrence of significances, fat foods scored the third highest (3), favouring the inadequate food intake households.

Animal sourced foods provided significantly higher proportion of vitamin $E$ and Vitamin A to inadequate food intake households for the first and second round respectively. Referring recurrence of significances, the animal sourced foods scored 2, being the last influential food group in household intake variation.

In summary, based on both homogeneity of variances test and analysis of variances, vegetables and fruits were found to have remarkable positive contributions (quantity) to household food intakes. Where vegetables and fruits as well as starch food groups were significantly associated with household food intake adequacy, fats and animal foods were associated with inadequacy of food intake. Legumes group of food contributed significantly to both inadequate and adequate food intake households.

\section{DISCUSSION}

The importance of food groups to households in relation to food intake was assessed using a score of 1 to $5(1=$ least important; $5=$ most important $)$. Scaling of 1 to 5 was done considering the five food groups involved (see Table 6). 
Table 6. Scores for importance of food varieties to households, Nov. 2004/ March 2005

\begin{tabular}{|c|c|c|c|c|c|c|c|c|c|c|}
\hline \multirow[t]{2}{*}{$\begin{array}{l}\text { Element / } \\
\text { households }\end{array}$} & \multicolumn{5}{|c|}{ November 2004} & \multicolumn{5}{|c|}{ March 2005} \\
\hline & Starchy & Legume & Veg/fruit & Fats & Animal & Starchy & Legume & Veg/fruit & Fats & Animal \\
\hline \multicolumn{11}{|l|}{ Energy } \\
\hline Inadequate FIH & 5 & 3 & 2 & 4 & 1 & 5 & 4 & 1 & 3 & 2 \\
\hline Moderate FIH & 5 & 3 & 1 & 4 & 2 & 4 & 5 & 1 & 3 & 2 \\
\hline Adequate $\mathrm{FIH}$ & 5 & 3 & 1 & 4 & 2 & 5 & 4 & 1 & 3 & 2 \\
\hline Sub Total & 15 & 9 & 4 & 12 & 5 & 14 & 13 & 3 & 9 & 6 \\
\hline \multicolumn{11}{|l|}{ Protein } \\
\hline Inadequate FIH & 5 & 3 & 2 & 1 & 4 & 4 & 5 & 2 & 1 & 3 \\
\hline Moderate FIH & 5 & 3 & 2 & 1 & 4 & 4 & 5 & 2 & 1 & 3 \\
\hline Adequate $\mathrm{FIH}$ & 5 & 3 & 2 & 1 & 4 & 4 & 5 & 2 & 1 & 3 \\
\hline Sub Total & 15 & 9 & 6 & 3 & 12 & 12 & 15 & 6 & 3 & 9 \\
\hline \multicolumn{11}{|l|}{ Iron } \\
\hline Inadequate FIH & 5 & 4 & 3 & 1 & 2 & 4 & 5 & 3 & 1 & 2 \\
\hline Moderate FIH & 5 & 4 & 3 & 1 & 2 & 4 & 5 & 3 & 1 & 2 \\
\hline Adequate $\mathrm{FIH}$ & 5 & 4 & 3 & 1 & 2 & 4 & 5 & 3 & 1 & 2 \\
\hline Sub Total & 15 & 12 & 9 & 3 & 6 & 12 & 15 & 9 & 3 & 6 \\
\hline \multicolumn{11}{|l|}{ Vitamin A } \\
\hline Inadequate FIH & 4 & 2 & 5 & 3 & 1 & 5 & 3 & 4 & 1 & 2 \\
\hline Moderate FIH & 4 & 1 & 5 & 3 & 2 & 4 & 3 & 5 & 2 & 1 \\
\hline Adequate $\mathrm{FIH}$ & 5 & 1 & 4 & 3 & 2 & 5 & 3 & 4 & 2 & 1 \\
\hline Sub Total & 13 & 4 & 14 & 9 & 5 & 14 & 9 & 13 & 5 & 4 \\
\hline \multicolumn{11}{|l|}{ Vitamin E } \\
\hline Inadequate FIH & 4 & 1 & 2 & 5 & 3 & 4 & 1 & 2 & 5 & 3 \\
\hline Moderate FIH & 4 & 1 & 2 & 5 & 3 & 4 & 1 & 2 & 5 & 3 \\
\hline Adequate $\mathrm{FIH}$ & 4 & 1 & 2 & 5 & 3 & 4 & 1 & 2 & 5 & 3 \\
\hline Sub Total & 12 & 3 & 6 & 15 & 9 & 12 & 3 & 6 & 15 & 9 \\
\hline $\begin{array}{c}\text { Grand Total } \\
\text { Overall }\end{array}$ & 70 & 37 & 39 & 32 & 37 & 64 & 55 & 37 & 35 & 34 \\
\hline importance & 1 & 3.5 & 2 & 4 & 3.5 & 1 & 2 & 3 & 4 & 5 \\
\hline
\end{tabular}

Scaling was done with regards to proportions of household energy, protein and micronutrients obtained from food groups (see Table 5). The overall importance of the food type in providing energy, proteins and micronutrients was obtained by adding the specific household food intake scores. Therefore, the food group which obtained a total score of 15 was the most important provider of the specific nutrition item (energy, protein and iron, Vitamin A and Vitamin E). The food group which obtained a total score of 3, was the least important provider of the specific nutrition item. Therefore, 3 and 15 are in the extremes of the scale. 
An example of this is the case of starchy foods where starch was a very important energy providing food during the first round (scoring 15), while animal foods was the least important food energy provider during both surveys (scoring 3). Assessment of the food importance across two seasons, indicated the overall importance of food groups to Embo community.

Starch and fat foods were the most important sources of energy during the first round, where legumes and starch occupied the same level of importance during the second round. Vegetable and fruits were the least important source of energy for both rounds. Starch and animal foods were the most important sources of protein during the first round, while legumes and starch were most important during the second round. Fat foods were the least important source of protein in both rounds. Starch and legumes foods were the most important sources of iron during both rounds. Similar to the case of protein, fat foods were the least important source of iron for both rounds. Fruit / vegetable and starch foods were the most important sources of vitamin A during both rounds. Legumes and animal foods were the least important source of vitamin A for round 1 and 2 respectively. Fats and starch group of foods where the most important sources of vitamin E during the both rounds, legumes were the least important source of vitamin $\mathrm{E}$ for both rounds.

The grand total (summation of subtotal) for food group scores provided the overall importance of food (Table 6). The most important food group for each round was the one with highest grand total value, while the least important food was the one with lowest grand total value. While the most important food for the season was marked 1, the least important food for the season was marked 5. During both rounds, starch was 
the overall important food group. In order of importance, starch was followed by vegetables and fruits, legumes and animal foods and lastly fats during first round. During the second round, starch was followed in order of importance by legumes, vegetables and fruits, fats, and lastly animal foods. Seasonality influenced the variation of availability of foods, whereby there was less and plenty during the first and second round respectively.

As mentioned earlier, an overall importance of food group was done by calculating averages of overall importance scores of food groups from both rounds. Starch foods scored an average of 1 making it the most important food group. Following starch in order of importance were vegetables and fruits (2.5), legumes (2.75), fats (4) and animal foods (4.25).

With reference to the South African Food Based Dietary Guidelines, the quality of households' meals (with regards to five food groups) were analysed across the two seasons. "Making starchy foods the basis of most meals" was principally in practice during both rounds as starch foods were found to be the most important food during both rounds. "Eating plenty of fruits and vegetables" was met since fruits and vegetables maintained the overall second position across seasons. As the guideline "Eat dry beans, peas, lentils and soya often" (legumes), was proposed in understanding that consumption of more legumes promote overall health, household diets were observed to adhere to this since the legume group of foods scored an overall of the third important foods for households. 
Fat foods, obtained the fourth order of importance to households in both rounds. Foods sourced from animals have been the last important food to households. Though Scholtz et. al, (2001) argument that animal food can be eaten everyday - not a conundrum was made in realisation that food sourced from animal are important nutritionally and excessive intake increases risk of chronic diseases, the current finding relates low intake to poverty persisting in Embo as most households struggled to meet nutritional requirements. Both high importance of starch, vegetables and fruits and legumes as well as little importance of animal sourced food and fat foods reflected adherence to South African Dietary Based Guideline.

\section{CONCLUSIONS}

The current study showed that it is possible to relate food intake to both food diversity and quality in Embo community. Food intake was found to be positively associated with food diversity. Higher quantities of starch, fruits and vegetable and legumes were found to be necessary for households to have adequate levels of food intake. As long as starch foods have been found to be the most important food group the group can still be relied in preparation of food security matrices. Food diversity and quantity taken can make an aggregate measure for household food quality without being limited to micronutrients intake. Further similar studies are required to be conducted widely for the current findings to become empirical.

The findings suggested that South African Food Dietary Based Guideline is relevant to Embo community. The dietary trend (quality) was almost more or less the same across seasons and households irrespective of their food intake strata. Household 
dietary quality was found to be a bit improved during the second round as compared to the first round. Seasonality explains on the improvement of household diets during the second round. The current study revealed that household dietary quality was better maintained during the season of plenty (second round). Income poverty has also been realised as a limitation for households to acquire animal sourced foods and potential to hinder micronutrients intake. Better diets are therefore functional to seasonality and income poverty.

Since dietary quality is seasonally disrupted, there should be plans to maintain quality of diets during the time of less food. Less availability of legume food during period of less increased the importance of animal food during period of less. Availability of alternative legumes / source of proteins for particular season is highly recommended. Reduction of income poverty is pertinent to improve nutrition status of the Embo community. Interventions to promote Income Generation Activities (IGA's) to the community will improve nutrient intake of the respective community.

\section{ACKNOWLEDGMENTS}

The authors extend sincere appreciation to The South African National Research Foundation (project no. TTK2007052000011) for a scholarship to pursue this study, Ford Foundation, South Africa (Grant no. 1035-1796) for funding the survey from which this study drew. The study would not be possible if Embo community did not provide warm cooperation, the LIMA Rural Development Foundation for assistance in data collection and Shannon Moffett for data input and organisation. 


\section{ABBREVIATIONS}

FBDGs $=$ Food Based Dietary Guidelines $($ HFII $)=$ Household Food Intake Index, $\mathrm{NAR}=$ Nutrients Adequacy Ratio,

\section{REFERENCES}

Alasfoor D, Rajab H, Al-Rassasi B: Food Based Dietary Guidelines Technical background and description: Omani Food Based Dietary Guidelines. (http://www.fao.org/ag/humannutrition/195420561250979706400b7cc8ca7366cc07c0.pdf ) site visited on April 2013

Booysen F: Urban - rural inequality in health care delivery in South Africa.

Development Southern Africa, Vol. 20, No. 5, December. 2003

Camp KGT: The Bioresource Units of KwaZulu-Natal. Cedara Report N/A/95/32. Pietermaritzburg: KwaZulu-Natal Department of Agriculture, 1995.

Department of Health: Eradicate Extreme Poverty and Hunger: Target 1: Halve between 1990 and 2015 the proportion of people whose income is less than US\$1 per day, 2000.

Drewnowski AS, Henderson A, Driscoll A, Rolls B: The Dietary Variety Score: Assessing diet quality in healthy young and older adults. Journalof the American Dietetic Association 97: 266-271,1997. 
Farm and Food Policy Project: Making Healthy Food More Accessible for Low-Income People: Edited by Anderson, MD. 2007.

Fawzi WW, Msamanga GI, Spiegelman D, Wei R, Kapinga S, Villamor E, Mwakagile D, Mugusi F, Hertzmark E, Essex M, Hunter DJ: A Randomized Trial of MultivitaminSupplements and HIV Disease Progression and Mortality. New England Journal of Medicine 2004;351:23-32, 2004.

Food and Agriculture Organisation: Food and Agriculture Organization of the United Nations. Extracts from International and Regional Instruments and Declarations, and other Authoritative Texts Addressing the Right to Food. (Rome: $\quad$ FAO $\quad$ Legislative $\quad$ Study $\quad 69, \quad$ 1999). http://www.fao.org/Legal/Rtf/legst68.pdf, site visited on February 2012,1999.

Frey, B: Duncan's Multiple Range Test. In N. Salkind (Ed.), Encyclopedia of research design. (pp. 395-396). Thousand Oaks, CA: SAGE Publications, Inc. doi: 10.4135/9781412961288.n124. (2010).

Grillenberger M, Neumann CG, Murphy SP, Bwibo NO, Weiss RE, Jiang L, Hautvast JGAJ, West CE: Intake of micronutrients high in animal-source foods is associated with better growth in rural Kenyan school children. British Journal of Nutrition. 95, 379-390 DOI: 2006

Grobbelaar A, Le Roux M, Lindenberg C, Marais D, Steyn NP: Evaluation of usual dietary intake of women working on farms in the Koue Bokkeveld district and 
the potential benefits of maize and wheat fortification. The Southern African Journal of Epidemiology and Infection 2004; 19 (1) : 12-17. 2004.

Jones MJ, Klurfeld DM, Slavin J, Whybright S: Preparing for the 2015 Dietary Guidelines. Attributes of Refined Grains, Added Fibres and Bran. Vol 57 No. 2. AACC 2012.

Krebs-Smith S, Smiciklas-Wright H, Guthrie H, Krebs-Smith J: The effects of variety in food choices on dietary quality. J. Am. Diet. Assoc. 87: 897-903, 1987.

Lorenzana PA, Sanjur D: Abbreviated Measures of Food Sufficiency Validly Estimate the food Security Level of Poor Households: Measuring Household Food Security: Community and International Nutrition. Journal of Nutrition 129: $687-692,1999$.

Love P, Sayed N: Eat plenty of vegetables and fruits every day. The South Afican Journal Of Nutrition. Vol. 14, No.3, 2001.

Matthews A, George G, Gow J: The demographic impact of employment on HIVAIDS prevalence and incidence: Evidence from KwaZulu-Natal, South Africa. Health Economics and HIV/AIDS Research Division. KwaZulu-Natal, South Africa: University of KwaZulu-Natal.2008. 
Maunder EMW, Matji J, Hlatshwayo-Molea T: Enjoy A Variety Of Foods Difficult But Necessary In Developing Countries. The South Afican Journal Of Nutrition. Vol. 14, No.3, 2001.

Msaki MM, Hendriks SL: Measuring household food security using food intake indicators in rural KwaZulu-Natal. Journal of Ecology of Food and Nutrition in press, 2013.

National Academy of Sciences: Recommend Dietary Allowances. National Academy Press. Washington D.C.1989.

National Health and Medical Research Council: Food for Health - Dietary Guidelines for Australians. A guide to Healthy Eating. Department of Health and Ageing. Australian Government. 2005.

National Heart Foundation of Australia: Salt and Hypertension. Information from the Heart Foundation. Profession Paper No 555. 2007

Oelofse A, Van Raaij JMA, Benade AJS, Dhansay MA, Tolboom JJM, Hautvast JGAJ: The effect of a micronutrient-fortified complementary food on micronutrient status, growth and development of 6- to 12-month-old disadvantaged urban South African infants. Int. J. Food Sci. Nutr. 54: 399407. 27, 2003. 
Remans R, Flynn DFB, DeClerck F, Diru W, Fanzo J,Gaynor K, Lambrecht I, Mudiope J, Mutuo KP, Nkhoma P, Siriri D, Sullivan C, Palm CA: Assessing Nutritional Diversity of Cropping Systems in African Villages. PLoS ONE 6(6): e21235. doi:10.1371/journal.pone.0021235. 2011. (http://www.plosone.org/article/info\%3Adoi\%2F10.1371\%2Fjournal.pone.00 $\underline{21235}$ site visited on April 2013)

Rose D, Charlton K E: Quantitative Indicators from a Food Expenditure Survey Can Be Used to Target the Food Insecure in South Africa: Community and International Nutrition Journal of Nutrition 132:3235 - 3242, 2002.

Rose D, and Tschirley D: A simplified Methos of Assessing Dietary Adequacy in Mozambique. Research Report No. 36. Directorate of Economics, Ministry of Agriculture and Fisheries. Republic of Mozambique, 2000.

Ruel MT: Operationalizing Dietary Diversity: A Review of Measurement Issues and Research Priorities. J. Nutr. 133: 3911S-3926S, 2003.

Sani B: The Control of Seasonal Price Variations in Some Food Crops for Achieve to sustainable Economic Development. Paper presented in 2nd International Conference on Humanities, Historical and Social Sciences, IPEDR vol.17 IACSIT Press, Singapore. 2011

Stuijvenberg MV, Dhansay M, Smuts C, Lombard C, Jogessar V, Benadé A: Longterm evaluation of a micronutrient-fortified biscuit used for addressing 
micronutrient deficiencies in primary school children. Public Health Nutrition Journal. Volume 4, Number 6, December 2001, pp. 1201-1209(9), (2001).

Swindale A, Billinsky P: Household Dietary Diversity Score (HDDS) for measurement of Household Food Access: Indicator Guide VERSION 2.FANTA. 2006

Sydney Food Fairness Alliance: Where has all our food gone? Influences on the global food supply. Version 1. February 2009

UNAIDS: HIV and AIDS estimates and data, 2007 and 2001. 2008 report on the Global A id s E p i d e m i c. 24pp. 2008

United Nation Children's Fund: Achieving results for children. UNICEF Annual Report.2011.

Vella V: Maternal, Perinatal and Nutritional Conditions in KwaZulu Natal. Issue 3. KwaZulu Natal Epidimiology Bullet in, 2003

Vorster HH, Love P, Browne C: Development Of Food-Based Dietary Guidelines For South Africa - The Process. The South Afican Journal Of Nutrition. Vol. 14, No.3. 2001.

Woolard I: An overview of poverty and inequality in South Africa. Working paper prepared for DFID (SA), 2002. 
World Health Organization. Report of a WHO/FAO expert consultation 2003. Diet Nutrition and Prevention of Chronic Diseases; WHO technical report series 916. Food and Nutrition Bulletin. . 28(1): S38-S50. 2007

World Health Organisation: Preparation and Use of Food-Based Dietary Guidelines. WHO Technical Report, Series 880. Report of a Joint FAO/WHO Consultation. World Health Organization, Geneva, Switzerland, 1996.

Yong HY, Zalilah MS, Yap LD: Relation of Dietary Fat Intake Perception to Nutritional Status and Psychosocial Factors. Malaysia Journal of Nutrition 15(2): $195-204.2009$ 